\title{
Novedad Editorial
}

Se acaba de publicar el libro Ciudadanías conectadas. Sociedades en conflicto. Investigaciones sobre medios de comunicación, redes sociales y opinión pública (Bogotá: Universidad del Rosario, 2018), texto editado por Carlos Charry, Profesor de Sociología de la Universidad del Rosario y miembro del Observatorio del Conflicto Social.

Como se indica en la presentación de esta obra, las investigaciones que se presentan, si bien tienen orígenes teóricos, metodológicos y disciplinares distintos, buscan en su conjunto dar respuesta a las realidades y conflictos sociales que han marcado el desarrollo de la sociedad contemporánea, marcada por la configuración de lo que Castells denominó como la "sociedad en red", dando cuenta de las implicaciones políticas y culturales de dicho fenómeno.

En el primer capítulo de este libro, titulado "Medios de comunicación, poder y sociedad" el Profesor Milciades Vizcaino, hace un recuento por los diferentes enfoques que se han encargado de resolver la relación entre esas tres variables, dando cuenta de algunas betas que serán indispensables para comprender los capítulos subsiguientes, constituyéndose en una forma fácil y amena de comprender la evolución que ha tenido el campo de estudios en comunicación y sociedad.
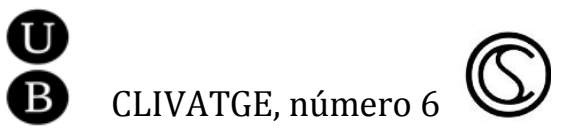
Por su parte, el profesor Luis Fernando Barón en el capítulo "Agentes, territorios y lenguajes de la acción política contemporánea: movilización juvenil, tic y esferas públicas" elabora una interesante y detallada comparación entre las formas de movilización social de los jóvenes en dos contextos específicos: el Movimiento Estudiantil de Colombia y del Movimiento de Reforma Migratoria en Estados Unidos (compuesto este último en su mayoría por hijos de inmigrantes latinoamericanos), dando cuenta de cómo las redes sociales han sido utilizadas por estos grupos como herramientas que van mucho más allá de la mera socialización, dando cuenta de amplio espectro de formas participación que desplegaron en los espacios públicos, constituyéndose en acciones colectivas mediadas por las Tecnologías de la Información y la Comunicación.

En el tercer capítulo, titulado "Mujeres que desvelan lobos. Análisis de dos movimientos de víctimas del conflicto armado colombiano, desde una perspectiva del campo de las ciudadanías comunicativas y el transnacionalismo" el profesor Camilo Andrés Tamayo Gómez y la investigadora Daniela Navarro, toman como caso dos movimientos de víctimas del Departamento de Antioquia (Colombia). A partir de tales experiencias de acción colectiva, Tamayo y Navarro analizan cómo las víctimas del conflicto armado se las han arreglado para darle un sentido a su tragedia y encausar dichos sentimientos y emociones en una nueva forma de ciudadanía y de lucha por los derechos, a partir de las dimensiones expresivas y comunicativas de la acción colectiva.

B CLIVATGE, número 6

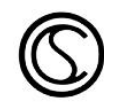


En un cuarto capítulo, Carlos Charry expone desarrolla una estrategia investigativa a través de la cual se busca dar cuenta del papel ejercido por los principales medios de comunicación colombianos en las dinámicas de formación de opinión pública en torno al proceso de paz. De esta manera, en "Rastreando la paz", tal y como se titula su capítulo, se pueden identificar las tendencias y los posicionamientos producidos en torno de este polémico proceso, que dividió a la sociedad colombiana entre partidario y opositores a los diálogos, dando algunas claves de lectura para entender por qué se llegó a niveles de polarización tan elevados.

El quinto capítulo titulado "La desmovilización de las FARC: ethos visual y rito de institucionalización”, a cargo del profesor José Fernando Sánchez, examina la reciente desmovilización de la hoy extinga guerrilla, a partir de un análisis de las estrategias de representación asumida por algunos de los medios de comunicación. De manera concreta, Sánchez aborda las imágenes que fueron producidas a partir del desplazamiento de dicha guerrilla a las zonas de desmovilización instauradas en diferentes partes de la geografía colombiana, en donde fue característico encontrar guerrilleras en tránsito a su reincorporación a la vida civil en estado de gestación o con bebes de pocos meses de nacimiento, lo que se constituyó en sí mismo en una forma de ethos visual.

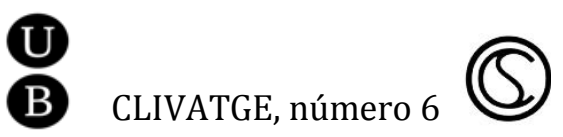


Por su parte, la investigadora Susana Angulo y el profesor Daniel Barredo, en su capítulo "El tratamiento periodístico de los movimientos sociales animalistas en Colombia: un estudio sobre El Tiempo, El Espectador, El Colombiano y Semana (2014-2016)" comparan el tratamiento dado por tales medios al movimientos animalistas, iniciativa que parte de un análisis de contenido manual, así como de la aplicación de la metodología del análisis estadístico de datos textuales. A partir de los datos generados, Angulo y Barredo logran evidenciar las estrategias comunicativas de los medios y las formas en cómo el movimiento animalista logró captar una mayor atención por parte de estos, siendo esta una experiencia que merece ser estudiada para el análisis de otros casos.

El libro termina con capítulo "Libertad de expresión, crisis de derechos humanos y periodismo en México. Legitimación, autocensura o persecución". En este pormenorizado análisis, desarrollado por los profesores Sandra Hincapie y Jairo Antonio López, se abordan la crisis que está viviendo el periodismo y los medios de comunicación en México, el cual es un reflejo de la crisis social que está viviendo ese país a raíz de la incursión del fenómeno del narcotráfico. Dicho capítulo ofrece un detallado itinerario por las violaciones a los derechos humanos a los periodistas, a partir del cual se puede identificar las dinámicas sociales que hacen que el oficio del periodismo sea vulnerado en ese país. De este modo el capítulo logra develar las razones por las cuales la impunidad de los crímenes cometidos se ha vuelto el común denominador, siendo esta una

B CLIVATGE, número 6

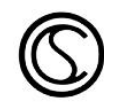


experiencia que puede ser comparable con otras sociedades de la región latinoamericana, tales como Colombia y más recientemente Venezuela, en donde el ejercicio del periodismo se ha visto afectado.

De esta manera Ciudadanías conectadas. Sociedades en conflicto. Investigaciones sobre medios de comunicación, redes sociales y opinión pública brinda un recorrido analítico por diferentes casos, dando cuenta de las transformaciones sociales del mundo contemporáneo, teniendo la particularidad de exponer contextos donde operan diferentes grados de modernización, de integración y de institucionalización, evidenciando con ello la multiplicidad de dimensiones que se entrecruzan y conectan, siendo este un referente de lectura indispensable para quienes deseen incursionar en este campo de estudios. 